\title{
TOWARDS DIGITALIZATION IN INSURANCE MARKET: TELEMATIC INSURANCE
}

\author{
Muharrem UMUT*, Vocational School of Banking and Insurance, Ankara Haci Bayram Veli University, Turkey, \\ muharrem.umut@gmail.com \\ (iD) https://orcid.org/0000-0002-9213-1440)
}

Received12.03.2020, Accepted: 09-09-2020

Research Article

*Corresponding author DOI: $10.22531 /$ muglajsci.702898

\section{Abstract}

A new type of insurance where information technology is widely used has emerged in the field of digital insurance: telematics insurance. By receiving the real-time data of the insured with the help of telematics devices containing carconnected technology, telematics insurance plays an important role in determining the risk of the insured and calculating the right premium accordingly. The insurance offers a more accurate and fair pricing opportunity based on usage behavior (Usaged-Based Insurance, UBI) data, such as driving distance, driving area, acceleration and braking conditions, what time of day the vehicle is used, as well as personal information. Telematics insurance is an important factor in distinguishing risky and non-risky drivers, reducing the insurance premiums of less risky drivers, changing the driver habits and directing people to more careful driving, thereby reducing the number of accidents that cause material and physical damage.For the telematic insurance to be implemented in our country, it is recommended that the ipplementation be carried out through the Insurance Information and Monitoring Center, where all insurance data is kept in one center and made available to the insurance market, rather than establishing insurance companies' own infrastructure.

Keywords: Information technology, Digital insurance, Telematic insurance, Driver behaviors, Usaged-based insurance

\section{SİGORTACILIK PIYYASASINDA DİJITALLEŞMEYE DOĞRU: TELEMATİK SİGORTA}

\section{Özet}

Bilişim teknolojisinin yaygın olarak kullanıldığı dijital sigortacılık alanında yeni bir sigorta türü doğmuştur: telematik sigorta. Telematik sigorta, bağlantılı araç teknolojisini içeren telematik cihazlar yardımıyla sigortalıların gerçek zamanlı verilerini alıp, sigortalının riskinin tespitinde ve buna göre prim hesaplamasının yapılmasında önemli bir rol oynamaktadır. Söz konusu sigorta, kişiye özgü bilgilerin yanı sıra sürüş mesafesi, aracın kullanıldığı bölge, hızlanma ve fren durumları, aracın günün hangi saatinde kullanıldığı gibi sürücü davranışlarına ilişskin ve kullanıma dayalı (Usaged-Based Insurance, UBI) veriler üzerinden daha doğru ve adil bir fiyatlama imkânı sunmaktadır. Telematik sigorta, riskli ve risksiz sürücülerin ayırt edilmesinde, daha az riskli sürücülerin sigorta primlerinin azaltılmasında, sürücü alışsanlıkları değisştirilerek kişileri daha dikkatli araç kullanımına yönlendirmede, böylece maddi ve bedeni hasarlara yol açan kazaların sayısının azaltılmasında önemli bir etken oluşturmaktadır. Telematik sigorta türünün ülkemizde uygulanabilmesi için her bir sigorta şirketinin kendi alt yapısını kurmasından ziyade; uygulamanın, tüm sigortacıllk verilerinin tek bir merkezde tutulduğu ve sigorta sektörünün kullanımına sunulduğu Sigorta Bilgi ve Gözetim Merkezi üzerinden yürütülmesi önerilmektedir. Dünya sigorta piyasalarında sunulmakta olan telematik sigortanın önümüzdeki dönemde öneminin ve payının gittikçe artacağı beklenmekte olup, ülkemiz sigortacılığında da bir an önce hayata geçirilmesinin önemli olduğu düşünülmektedir.

Anahtar Kelimeler: Bilișim teknolojisi, Dijital sigortacılık, Telematik sigorta, Sürücü davranışları, Kullanıma dayalı sigorta Cite

Umut, M., (2020). "Towards Digitalization In Insurance Market: Telematic Insurance", Mugla Journal of Science and Technology, 6(2), 1-10.

\section{Introduction}

In today's information and technology era, rapid changes and developments have been experienced recently. Especially developments in information systems show themselves rapidly in the fields of transportation, infrastructure, health and energy as well as the financial sector. Indeed, thanks to innovations in technology, access to information has become extremely fast, easy and inexpensive, and individuals have become more using technology [1]. Today, individuals are increasingly researching the products they need more and more, primarily through internet and information-based systems, have extensive knowledge about these products, compare prices, and purchase the most suitable products using technology. Therefore, these developments directly affect the daily life of the individual, and then people carry out many daily 
operations through the information system. One of the areas where information technology is widely used is the insurance market in the field of finance. In the market in question, insurers use internet-based information technologies while researching the product that suits them best and purchase the insurance policy through distribution channels or directly through the insurance company by making a price comparison. Undoubtedly, the issue that the insured focus most and approaches with precision is the insurance prices.

In our country, insurance prices have increased continuously due to the economic conditions. Therefore, the insured is searching the options for reducing insurance related payments and wants to purchase the most economical policies for them. While the share of compulsory traffic and collision (kasko) insurance, which has the highest density and number of policies in our country, in total premium production is $48.1 \%$, the share of compulsory traffic insurance in the liability insurance is $87 \%$ [2]. As can be seen, the level of premium production and insurance price in motor vehicle insurance is vital for both insurers and policyholders.

Currently, premiums for motor vehicle insurances are calculated by taking into account basic information such as the past damage information of the driver, the type of vehicle and the province where the license plate is located. However, in this calculation, the full and correct pricing is not realized since the insured's driving experience and personal information are ignored. The premium calculation method based on a fixed price does not penalize negative driver behavior, does not encourage careful driving and does not prevent excessive use of vehicles to reduce environmental pollution. In this case, with the increase in the number of accidents and traffic density, environmental pollution increases, besides, while the risk-free drivers are not rewarded, the risky drivers are not punished. This result shows us that some insurers with high risk in traditional pricing pay less than they should and some insured people with low risk pay more than they should.

In person-based and driver experience-based policies, risk profiles of individuals are created based on personal damage records, usage style, driver behaviors, and as a result, more accurate, reliable and fair pricing opportunities are provided. In the traditional premium determination method, while a premium amount is determined at the beginning based on the basic criteria, in the usage-based system, although a premium amount is determined at the beginning, the premium amount may change, increase or decrease according to the driver's behavior at the end of the policy year. In other words, in person-based and usage-based insurance policies, a premium can be calculated in a healthier way, as the risk is calculated according to each driver's driving experience (vehicle use in kilometers, driving behaviors / characteristics) [3].

For person-based and usage-based policies, taking into account personal data, information about driving time, distance and driver behavior is evaluated and an insurance price is formed accordingly [4]. Telematic insurance, which includes the mentioned elements, will be able to distinguish between risky drivers and risk-free drivers, and in this case drivers with less risk will have the opportunity to obtain a lower premium insurance. Thus, the insured will think that the driver's behavior is monitored and that they will pay less premiums as they drive more carefully, so the risk profiles can be improved. With the decrease in risk in motor vehicle insurance, the number of accidents that cause material and physical damage will decrease, damage costs will decrease, environmental pollution will be prevented by using less vehicles, and then social benefit will increase with insurers and insurers [5].

Telematics devices with smart transportation systems are used to provide data on driving amount and driver behavior. Telematics devices consist of 'connected vehicle technologies' such as black box, smartphone applications, external memories, which store real-time data, transmit this data to the insurer and are currently used in the insurance market [6]. Telematics devices are also called telematic vehicle systems that are installed on vehicles and provide the necessary communication between the driver and the road and the automobile. Mobile technologies are the new generation systems that eliminate the distance and time difference between the insurance company and the insured, and enable and facilitate information flow and mutual communication through these technologies [7]. Although it is mostly known as black box in practice, in addition to the applications downloaded to mobile phones, all of the electronic products such as devices installed externally on the vehicle lighter section, battery line or vehicle windshield and external memories are called telematic devices and telematics insurance products are offered to the insured [8]. Therefore, collecting and using sufficient data for the correct determination of the person's insurance risk and policy price is currently possible with the help of telematics devices. In addition, in terms of insurance technique, the most suitable option that takes into account the driver behavior, the amount of driving and personal data together is the use of telematics devices and, accordingly, the introduction of new insurance products.

In world practices, policies based on the use of telematic devices in the European region and the United States of America (USA) are offered to the insured as an alternative option and become widespread [9]. The country with the most common use in the world is Italy. In countries where policies based on the use of these telematics devices have become widespread, it has been observed that the driving quality and accident rates decrease with telematics insurance [10].

On the other hand, the use of telematics devices and related insurance products is extremely limited in Turkey. It is seen that only one insurance company has a telematics device-based insurance application to be used in the insurance branch. It is thought that it will be appropriate to develop telematic device-based insurance 
products and offer them as an option to the insured, as the prices continue to increase in motor vehicle insurances, especially in compulsory traffic insurance in our country. Thus, more realistic premium prices will be created by taking the insured's usage style and personal information into consideration, and it will be possible for the insured with a more positive driving style to have cheaper insurance. Our country has a great potential in terms of both the insurance market and its young population in the context of these practices.

In order to achieve the goals such as catching up world practices, providing more accurate and fair pricing in accordance with the risk profiles, finding lower premium insurance products, reducing uninsurances, lowering the number of accidents and ensuring the development of the insurance sector, telematic insurance should be generalised and preparatory studies should be carried out in this regard immediately.

In the study, first of all, studies on the use of telematicsbased insurance products will be mentioned, and then information will be given on why telematics insurance is needed in our country's insurance market. Then, insurance types based on the use of telematics devices and the advantages and disadvantages of these types will be outlined and they will be assessed for the use in Turkey's insurance market. Finally, recommendations will made.

The study is considered to contribute to the generalization of telematics insurance in our country.

\section{Literature Research}

In the literature research on the subject, it was seen that many studies were conducted. As of the scope of the study, the studies that telematics insurance products give more successful results and produce realistic prices by determining the risk level more accurately are listed below.

According to Litman (2011), the use of telematics devices plays an important role in reducing the premium amounts, leads people to use vehicles less, and because of the premium discount, people prefer more telematics insurance products [11].

Bolderdijk et al. (2011), in a study conducted on young drivers, it was found that telematics insurance, which takes into account driver behavior, is significantly effective in reducing speed violations and provides a great advantage in developing drivers' awareness of traffic rules [12].

In a study conducted by LexisNexis (2014), it was found that there was no statistical correlation between the traditional prices and driver ratings and thus, those who were over-risk were paying less than necessary and those in the risk-free group paid more than they should. It has been demonstrated that policies based on usage obtained from telematics devices are preferred by the insured, and fair and accurate pricing is made by using data that takes into account driver behavior [13].
In a study conducted by Bruneteau (2015), it has been determined that the telematic applications positively affect the insured behavior and have an important function in reducing the insured risks [9].

In a study conducted in Eastern European countries; It has been stated that usage-based policies will be particularly useful in developing countries and that these countries will be successful examples of this new type of insurance in terms of their insurance potential [4].

In a study conducted in Italy, it was found that the telematic insurance products were preferred by the insured who pay high premium, in other words, there is a linear relationship between the premium amounts paid and the preference of the policies based on usage [10]. In an analysis conducted by Weidner \& others (2017) on the insured data of a large insurance company in Germany, it has been revealed that telematics products are very successful for classification of risk and accurate pricing in the short and medium term [14].

According to Bian et al. (2018), the traditional insurance premium calculation method is incomplete and the insured driver behavior and distance driven play an important function in reducing insurance premiums [15].

\section{Preferability of Telematics Insurance and Innovations Offered}

Telematics devices are used in the insurance markets of the developed countries like England, Germany, Italy, France and the USA, and telematics device-based insurances are highly preferred by the insured who do not want to pay high premium [4]. In general, drivers with low risk (committing less mistakes) but paying relatively high premiums seem to prefer telematics products [11].

Italy is the country where the use of telematics devices is the most widespread in the world and accordingly the insurance policies based on the use of these devices are purchased the most. Telematics based insurance has been applied in the country since 2003 and telematics insurance policies are offered by all insurance companies in the market. As of the end of 2017, it was determined that 6.3 million insured people are using these products (20\% of all policies are telematics-based insurance policies). [16].

Although telematics devices are commonly used in the UK, telematics insurance products are mostly used for young people with aggressive and hard driving style and inexperienced drivers. Telematics-based insurance, which was put into practice for the first time in 1990, is preferred by 3.1 million people as of the end of 2018 [17].

As it can be seen, telematics insurance, which is a highly preferred product in developed countries, offers insurers who pay high premiums to pay a lower amount of premium. It is understood that telematics insurance is a very successful system in determining the risk of the insured correctly. As a matter of fact, in the policies based 
on person and usage; more accurate, reliable and fair pricing can be made by creating brief risk profiles. In other words, in telematics insurance products, it is possible to calculate healthier premiums, as the risk of each driver is calculated separately according to the mileage and driving behaviors / characteristics. Thus, alternative insurance products can be offered to the insured with the help of telematics devices that control the amount of driving and driving behavior or record this data in real time and transmit it to the relevant center.

Another innovation offered by telematics insurance is the elimination of information asymmetry, which expresses the fact that the insurer does not have the same level of information with the insured. Insurers reach more accurate and reliable data in evaluating risk and calculating premium level with telematics devices. Thus, insurance companies receive the right premium according to the risk, while the insured pay the appropriate premium according to their risk level and telematics insurance has an important function in establishing the basis of mutual trust. However, telematic device-based insurance policies will lead people to drive more carefully, thus helping to reduce accidents.

With the Telematics insurance, companies will have a wide range of data, so their portfolios will be diversified and they will be able to offer a wider range of insurance products to the insured. As a matter of fact, new insurance products will be developed for those who will buy an insurance policy, taking into account their insurance needs and providing premium payments commensurate with their own risks. Therefore, the biggest innovation in terms of telematic device-based insurance policies will be the product range. These telematics insurance products are discussed in the next section.

\section{Types of Telematics Insurance Products}

\subsection{Usage-Based-Insurance (UBI)}

It is a dynamic type of insurance that takes into account personal driving behaviors such as speed, mileage, vehicle usage location, time, travel pauses with the help of telematics devices during the policy period [4]. UsageBased Insurance, where the coverage and premium level of the policies may change according to the driving behavior of the insured, has widespread use in the world.

\subsection{Pay-As-You-Drive (PAYD)}

It is a method in which only the driving distance is automatically transmitted (by remote access method) to the insurance company via the black box placed in the vehicle [18]. At the beginning of the policy, a kilometer is determined based on the person's declaration and premiums are made accordingly. At the end of the policy, when the mileage determined at the beginning is exceeded, additional premium payment is requested by the insurance company. The insurance company revises the insurance premium at the end of the year with the data provided. The purpose of this product is to ensure that insured people use less vehicles, thus reducing the risk in traffic and preventing accidents. According to statistics, it was observed that accidents with this insurance product decreased by an average of $15 \%$ per year [11]. A study conducted in the Netherlands showed that when PAYD is applied, the total accident rate can be reduced by more than $5 \%$ and there will be fewer fatal accidents in the Netherlands each year. However, the lack of the insurance is that it does not take into account driver behavior.

\subsection{Pay-How-You-Drive (PHYD)}

In the pay-as-you-go type of insurance type, real-time data such as the distance covered, the location of the motor vehicle, the time of day the vehicle is used, and the acceleration and braking use are collected and recorded [19]. In other words, a risk profile is created according to the vehicle usage style and policy covarage is determined accordingly. Since PAYD policies only consider the driving distance, PHYD policies have been developed as an alternative product and a new type of policy has emerged that uses driving style information as well as driving distance.

\subsection{Pay-At-The-Pump (PATP)}

Compared to PAYD and PHYD policies, it is a more primitive and simple type of policy pricing according to the fuel consumption of the person. The main criterion is the daily fuel consumption of the person and the final premium is created by adding a minimum policy premium based on fuel consumption data [20]. However, this method was not found efficient and not widely used due to the different fuel consumption of different vehicles. Consequently, it has not been preferred much by the insured since fuel-saving vehicles cause injustice for drivers who do not have those vehicles.

\subsection{Pay-Per-Mile (PPM)}

A similar type of PAYD policies, it is a method where the kilometer (or mile) to be covered is taken as a commitment at the beginning of the policy and then the price of the policy is determined. At the end of the year, the premium is revised taking into account the total mileage done, and additional premium may be raised in favor or against the insured. Since PPM policies are based on driver's declaration, there is a lot of change in premium amounts at the end of the year, so it is seen as an open to fraud [21]. For example, Butler et al. (1988) determined that $60 \%$ to $70 \%$ of the insured vehicles that are expected to travel less than $12.000 \mathrm{~km}$ per year, according to the driver's estimate, actually traveled approximately $20.000 \mathrm{~km}$ [22].

Therefore, PAYD and PHYD telematics policies have been developed by insurance companies after it has been revealed that this type of policy is not preferred too much.

In general, although the types of insurance mentioned in developed countries are applied, it is seen that the widely used telematics insurance products are usage-based insurance (UBI) products that take into account the usage style and driving distance [4]. In the study 
conducted by LexisNexis in 2014, drivers were classified by taking into account the credit rating of the drivers and other risk factors used in premium pricing using the scoring method. In the study, it was anlaysed whether driver behavior is a new criterion for existing pricing methods and whether traditional risk factors also include these behaviors. In this context, the driver points obtained by using the data set consisting of $23,000 \mathrm{UBI}$ policies and the premiums of policy holders determined by traditional pricing methods were compared and the results in Figure 1 were reached [13].

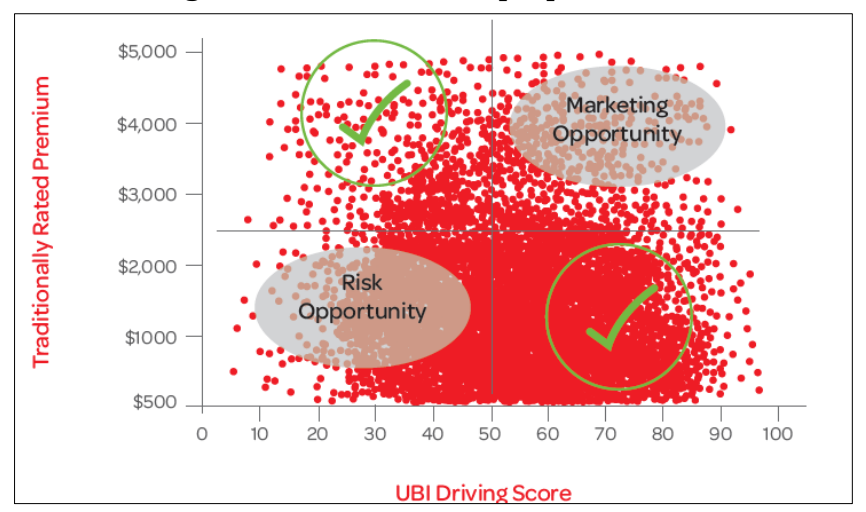

Figure 1. Correlation Between Traditionally Rated Premium and UBI Driving Score.

In the graph, there is almost no correlation between driver scores and premiums determined according to traditional pricing. This result shows us that, in traditional pricing, some high-risk insured pay less than they should be, while some low-risk insured pay more than they should. For this reason, using the data obtained from driver behaviors in pricing will create a fairer and more accurate premium distribution for the insured [3].

\section{Advantages and Disadvantages of The Insuance Based on Telematics Device}

Advantages: Telematics insurance provides services such as location determination, utilization of mobile and infrared communication, close-distance technologies, as well as providing road assistance and technical support to drivers with the help of devices. In this type of insurance, the real data of the insured are collected, resulting in more realistic results in terms of actuarial accuracy and pricing the person's risk. Thus, real-time data related to vehicle usage has an important function in accurately determining and pricing the risk of the persons. As a matter of fact, considering the risk factors of the insured, the Premium is calculated and then, as the database of the insured grows, risk calculation and policy pricing are more accurate in accordance with the large numbers law [23]. In addition, as instantaneous data is recorded, telematic insurance gives faster results and can be more efficient for both parties. Besides, it turned out to be a successful product in shortening claims payment periods and reducing costs. On the other hand, drivers will tend to be more careful in traffic and use vehicles that comply with traffic rules, considering that they are being watched [12].
Therefore, the biggest advantage of this insurance is that it offers a fairer and more accurate pricing to the insured. It also establishes trust by eliminating the problem of information asymmetry between the insured and the insurance company. It is an easier and acceptable system for both insured and insurance companies since it is acted on realistic data. This insurance is an important factor in reducing the premiums of drivers using telematics device technology and in decreasing insurance prices [9].

For the public authority, it is preferable that the number of uninsured vehicles will decrease as more people purchase insurance products when premiums fall. Nevertheless, accident rates will decrease in country as telematics insurance will lead the person to drive more carefully, and public expenditures will be directed towards increasing road safety. Since the telematic system encourages less driving, the spread of greenhouse gases into the atmosphere will decrease and environmental pollution will be prevented with the decrease in fuel consumption in the vehicles. Thus, the traffic density on the highways will decrease and action will be taken within the framework of the social responsibility principle. It will be possible to help the victims as it will be possible to access the location information of people in vehicle accidents and emergencies [3].

Using the information to be obtained through telematics devices, the needs of consumers can be determined more clearly, new insurance products can be developed and telematics insurance can be offered as an alternative insurance product to those who want to purchase insurance. Due to the use of these devices, it will be of great benefit that telematics insurance will bring many stakeholders together and create new employment opportunities. Finally, with the data to be obtained from telematics devices, tracking and finding stolen vehicles, detection and prevention of insurance fraud will become easier [24].

Disadvantages: The biggest problem in telamatic insurance is the keeping and processing of insured information. As a matter of fact, in addition to being difficult and costly to provide such data, insureds also hesitate to share their personal information and in some cases do not want to share them. Recording, protecting and storing vehicle location information via telematics devices causes drivers' reaction [25].

In addition, which of the data provided with the help of telematics devices will be essential in pricing and what their share will be another problem. Because in telematics insurance, much data both for personal and driver behavior is obtained, and it can be problematic and costly for insurance companies to reflect these on prices and to develop new software for this purpose [25]. The need for costly black boxes, which are widely used in telematic devices, and to be installed on vehicles later on, poses a separate problem. Since the electronic devices in question will need a lot of stakeholders to assemble, maintain, repair, use electronic systems in these devices, 
as well as to store, process and use the data to be obtained, there may be difficulties in ensuring the necessary coordination [27]. the black boxes as a telematic device, being costly and needing to be mounted afterwards on vehicles is another problem. Since the electronic devices will need a lot of stakeholders to assemble, maintain, repair, use electronic systems in these devices, as well as to store, process and use the data to be obtained, there may be difficulties in ensuring the necessary coordination [27].

Therefore, it is a major disadvantage for both insured and insurers that telematics devices are costly and drivers are not willing to share their personal information. Furthermore, the absence of data obtained from telematics devices at the beginning of the insurance period will create a disadvantage in determining the risk of the insured and correct pricing.

\section{Model of Telematics Insurance}

Although each country has developed its own usagebased telematic insurance model, the model shown in the figure below is widely accepted in the insurance market. Therefore, the model below depicts the technical stages, overview and architecture of the real-life telematic insurance system used in the market [4]. It also provides information on the data model that will form the basis of the telematic system. Because it is essential to ensure a regular and reliable data flow for this system to give correct results and to operate properly.

As seen in Figure 2, the two basic elements of the architecture in telematics insurance are data collection and reporting. Mentioned before, data collection is done by telematic devices such as applications of mobile phones and black boxes, electronic products such as devices installed externally on the vehicle lighter section, battery line or vehicle windshield and external memories. But mobile phones are the easiest and most widely used. The data coming to devices are raw data. The accuracy and reliability of the obtained raw data is very important for the usability of the system. Incoming data is collected on servers through applications or other devices. In today's lastest technology, the information is widely stored and used in the cloud service. Then, data are processed with the help of data analysis systems and made ready for insurer's use. In other words, the reporting stage is starts here. On the right hand side of the figure, it's shown that the reporting is produced by the insurance company using the online dash portal. After all these processes, the data becomes ready for pricing and use of telematics insurance.

Telematic devices are important technology tools in terms of sending, receiving and recording data about vehicles driven using information and communication technology. Especially in vehicles produced according to the latest technology, it has become easier to obtain information about vehicles through computer hardware or electrical devices. However, the accuracy of the data received via GPS is very important. Because GPS or similar technological devices are affected by environmental and weather conditions and can put the security of information at risk. Therefore, time is needed for this information to be checked, analyzed, processed and ready to use by comparing it with information such as GPS algorithms and map matching. After that process, information coming due to environmental and weather conditions and causing erroneous results can be

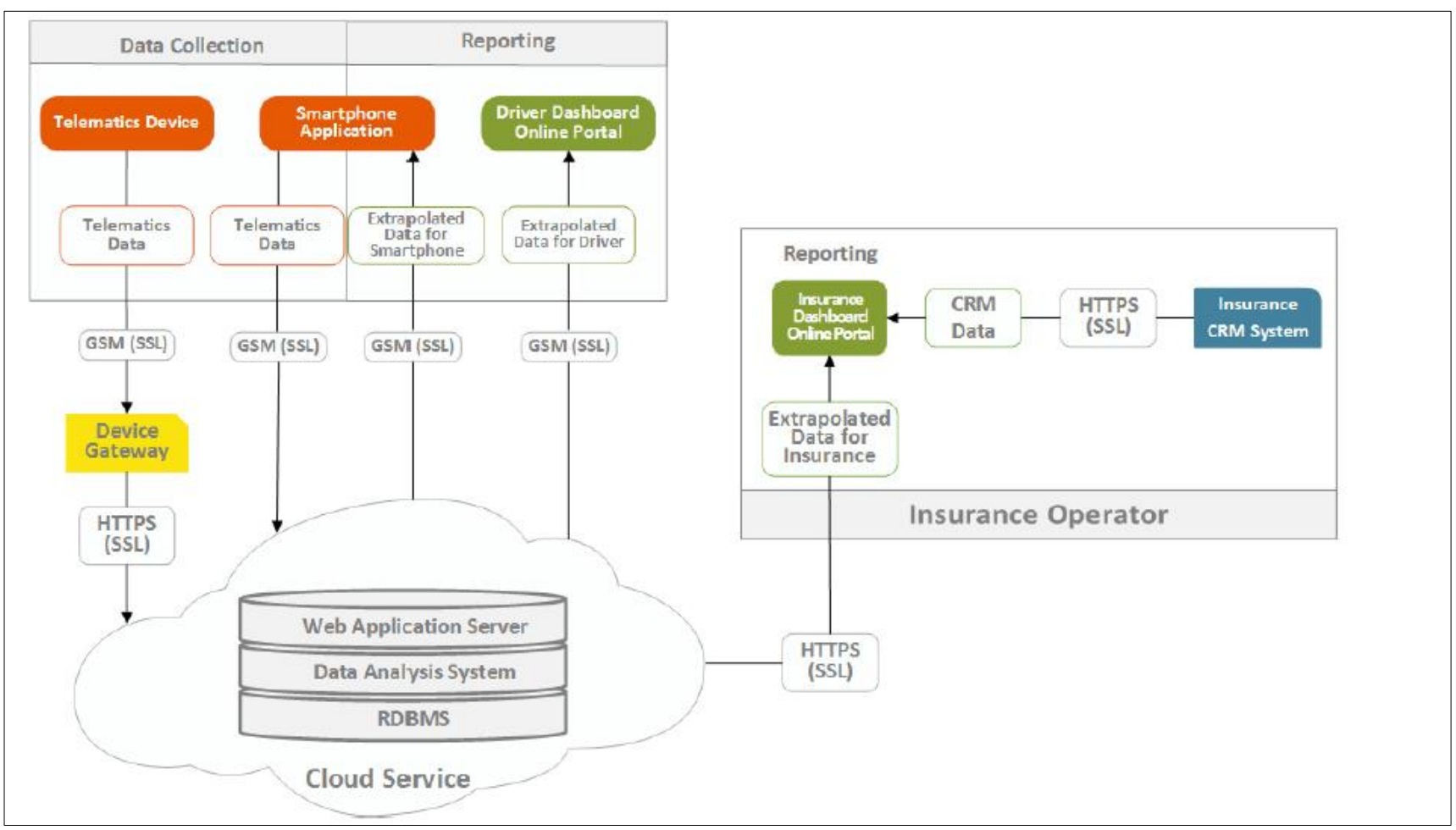

Figure 2. A Model of Real-Life Telematics Insurance [4]. 
eliminated and correct results can be achieved.

\section{A Recommendation Regarding the Applicability of Telematic Insurance in the Turkish Insurance Market}

While collision (kasko) insurance, which is one of the motor vehicle insurances in our country's insurance sector, is voluntary, there is a legal obligation to purchase the traffic insurance. A risk insured pool was established in 2017 in compulsory traffic insurance, and insurance premiums are determined by the relevant public authority. In kasko insurance, each insurance company in Turkey has its own traditional premium determination methods based on information such as past damage, vehicle brand, model, license plate and residendial city. Therefore, the use of telematics devices suitable for international applications and the offering of insurance products based on these devices is extremely limited in our country's insurance market.

In our country, there is a very limited telematic insurance product that only one insurance company operating in the non-life insurance branch uses for automobile insurance. This product is evaluated by taking information about the driving style and the product is made available on the website. Then a scoring is made and the premium is determined accordingly. However, depending on the development of insurance prices and the large number of companies in our country, the transition of the insured to different companies is frequently experienced and the practice that remains exclusive to only one insurance company loses its meaning.

Therefore, it is thought that it would be appropriate to establish a telematics insurance infrastructure within the Insurance Information and Monitoring Center (SBGM), which is a data center responsible for keeping, storing and processing information about the insured statistics in our country within the scope of the relevant insurance legislation. As a matter of fact, it is among the duties of SBGM to process, transform and prepare the data for the use of insurance companies to be obtained through telematics. In addition, all traffic and kasko insurance policy production and claims data are kept in SBGM, the digital center of the insurance industry [28].

On the other hand, instead of keeping the data from telematic devices in each company's own database, collecting and using this data in a single center such as SBGM and making it ready for use by all insurance companies will provide in all aspects a significant advantage of the use of telematics devices in the market. Besides, in the system to be set up in SBGM, it is thought that the maximum compliance with privacy in the protection and storage of personal data will be an important factor for the insurers to prefer telematicsbased policies. Because SBGM has responsibilities obeying in Insurance Law No. 5684 and this center is audited by the relevant public authority [29].

Before the system is installed, it should be well analyzed and planned in terms of how the system will be implemented, which devices will be used in the system, whether it will be mandatory to use the system, what its basic levels will be, determining the cost and detecting and directing the perception on the consumer. The system to be constructed should be quite simple and understandable in terms of its implementation. In addition, incentives should be provided for the generalization of the use of the system, such as a premium discount at the beginning or a high discount for the next policy at the end of the year.

After all, costs will occur at the initial stage for the promotion and marketing activities to bring insurance products based on the use of telematics device to a preferable level for the insured. It will be important to allow appropriate time for these products to reach and settle in the insurance sector. Accordingly, it will be appropriate to gradually switch to the system where telematics devices are used. It is possible that the system can be applied to certain vehicle groups at the beginning and to all vehicle groups when it becomes more widespread and preferable in the market. As telematics devices, it is possible to choose black boxes that will provide the healthiest data and make people use these devices in their vehicles, which will have a relaxing effect on the use of their personal information. Naturally, since the cost of the devices will be an important factor, it will be appropriate to share the cost with the insureds or to choose the most advantageous device. Besides, taking into country practices in the world, it is very important to establish the telematics insurance system by considering the data such as which data will be taken as basis in determining the premium, with which weights the data will be used, whether the system will be mandatory or what kind of telematics devices will be preferred [3].

On the other hand, with the amendments made in Regulation on tariff implementation of the Ministry of Treasury and Finance on April 24, 2019, it was possible to use the penalty points applied to drivers as a result of traffic violations made by individuals and the penalties for seizure of driver documents in determining the insurance price [30]. Therefore, an important threshold has been exceeded with the ability to use driver's license and penalty points, which are an aspect of driver behavior, in the calculation of premiums, and the use of telematics insurance has been opened in our country.

Finally, with the new system to be established, a significant gain will be achieved in the insurance sector in our country and the sector will develop, both in terms of distinguishing risky drivers from low risky drivers in motor vehicle insurance and catching up world practices [3]. Furthermore, this system, in which driver behaviors will be taken into consideration, will play an important role in reducing the number of injuries and fatal accidents in our country. The system will provide a great advantage especially for the companies that have fleet vehicles and private sector companies for tracking, monitoring and reducing the accident rate [1]. Likewise, with the tracking of the drivers, the possibility of 
intervention in accidents and sending assistance in emergency case will arise.

\section{The Future of Telematic Insurance}

The importance of telematics insurance type based on driver behavior will increase in the coming period. It is expected that the number of people using telematics insurance will increase by $90 \%$ in the coming years. Because the number of users, which was 1.85 million in 2012, increased to 89 million in 2017 [31]. There is an expectation that this number will increase even more, especially in developing countries. Besides it is estimated that the usage level of the said telematics based insurance products will be $25 \%$ in developed countries in the next 5 years and approximately 100 billion dollars will be seen as premium production [32]. By 2030, it is expected that approximately 750 billion dollars of premium production will be reached [8]. On the basis of this information, it may be shown that consumers who pay less premiums are satisfied with telematics insurance and insurance companies pay less compensation due to the insured's accident rates decrease.

One of the factors that increase the costs of insurance companies is insurance frauds. It is exptected that this type of insurance will become more and more widespread, as telematics insurance is a successful system to struggle such fraud. As a matter of fact, it is stated that telematics or advanced mobile devices have an important function in reducing the frequency and severity of damage, preventing insurance fraud and reducing damage or claims costs [33].

In addition, it is extected that insurance companies will prefer telematics insurance with the developing technology. Because, in a study by Mckinsey, it is revealed that companies that create the most economic value in the world benefit more from digital and innovation systems and labor skills [34]. Telematics insurance in terms of its content is among the most important elements of digital insurance.

Further, telematics insurance may be applied not only in auto insurance but also in health insurance. Because, coverage is determined based on basic information such as age, health history and smoking in health insurances. It is anticipated that it will be meaningful to offer health insurance products with instant information such as the daily activity of the person and the walking time through telematics insurance channel, and then premium calculations based on more dynamic data [35].

In our country, the high number of young population and consequently young drivers will trigger telematics insurance in the sector. Because it will be an alternative type of insurance for young drivers in the high risk group and other drivers who want to pay a lower premium. For this reason, it is inevitable that insurance based on telematics will become widespread in our country in the near future.

Therefore, as the technological developments and the level of risk of the insured increases, telematics insurance will continue to be on the agenda and its importance will increase as a result.

\section{Conclusion}

It is seen that companies and related organizations operating in the insurance market have been making efforts to make more use of technological and digital applications day by day and enter the daily life of insureds with the help of digital devices [36]. As of today, it is observed that the insureds frequently use digital applications via black boxes, smart phones and the internet, and insurers have the desire to develop digital applications accordingly [37]. Because today, many financial products are marketed digitally and consumers can access these products very quickly [38].

Telematics insurance products are widely used in many countries around the world, in the European region and the USA. Telematics insurance is a new type of insurance that takes into account personal information and driver behavior, as well as traditional methods for determining the policy price. More specifically, it is a dynamic type of insurance that takes into account the driving behavior of people, such as driving speed, vehicle usage (in kilometers), where and at what times of day the vehicle is used, travel stops, etc. during the policy period.

Telematics insurance is very successful in obtaining realtime data of the insured, and determining and pricing the risk on an individual basis. In telematics insurance, more realistic results are achieved in terms of actuarial accuracy and pricing the person. Telematics and advanced mobile devices have been found to play an important role in reducing the frequency and severity of damage in motor vehicle insurances, thereby reducing injuries and fatal accidents, preventing insurance fraud and reducing damage/claims costs. Studies in the literature confirm these results.

In the world practices, methods such as "usage-based insurance", "pay-as-you-drive", "pay-how-you-drive", "pay-at-the pump", "pay-per-mile" are used as telematics types of insurance. However, it is seen that the most preferred method for those who want to purchase insurance is "use-based insurance, UBI.

With the help of devices that form the basis of telematics insurance, many services can be offered such as positioning location, using mobile and infrared communication, providing road assistance and technical support to drivers, locating and reaching the spot in emergency situations. The biggest advantage of telematics insurance is that it enables a more accurate and fair pricing. This type of insurance is a more reliable system since the real and instantaneous data of the drivers are used. Thus, insurance products based on telematic device are applied and preferred more easily and quickly for the insureds and insurers. In addition, the insurance makes it easier for especially risky groups and aggressive young drivers to access insurance products, and it is possible for those people to purchase insurance products with lower premiums. 
On the other hand, the biggest disadvantage of telematics insurance is the storage, processing and determination of which data will be used in pricing. Drivers are also concerned about sharing their personal information with insurance companies. Another disadvantage is that telematics devices and applications are costly.

It is possible to expand the telematic insurance in our country's insurance sector by taking into consideration the world practices, especially the efforts to eliminate these disadvantages. Since the development of software for business analytics and analysis that will help to convert, protect and process the data to be obtained with telematics insurance as well as turn it into meaningful data is costly; it is recommended that these transactions should be carried out through SBGM, a featured institution established by law, instead of insurers' establishing its own system. SBGM already has an important function in terms of storing, processing and preparing insurance data and making it available to the insurance market. Therefore, SBGM is considered to be the most suitable center for data collection and processing in telematics insurance. But before starting the telematics insurance system, it is important to plan and analyze issues such as the setup of the system, which telematics devices to choose, determining the stages of the system, managing the perception of the consumers correctly, making it simple and understandable, and encouraging elements for using the system. In addition, additional arrangements may be required to address customer concerns regarding the protection of personal information.

As a result, the worldwide popularity of telematics insurance is increasing with the many opportunities it offers to the insurance market. In this context, it is essential to expand telematic insurance in our country's insurance as soon as possible and to establish the system in the structure of SBGM to take advantage of the opportunities provided by telematics insurances, as well as to capture world practices and to develop the sector. With the introduction of telematic insurance, it will be possible to access easier insurance products for the insured in the risky group, thereby reducing the uninsurance rate and increasing the premium production in the insurance market. Ultimately, insurance based telematics will make a major contribution to the development of national insurance.

\section{References}

[1] Bilen, D. Y. (2016). Otomobil Sigortalarında BonusMalus (Ödül-Ceza) Sisteminin Geçirdiği Aşamalar ve Teknolojik Gelişmeler Işı̆̆ında Değerlendirmeler. HAZINE UZMANLIĞI YETERLIKK TEZİ. ANKARA: Yayınlanmamış Uzmanlı Tezi, HAZINE MÜSTEŞARLIĞI.Surname, A. (Editor, if any), Title of the Book, Publisher, Location, Year.

[2] Turkish Insurance Association. (2019, November 30). Resmi İstatistikler. Erişim Tarihi: 15.01.2020, http://www.tsb.org.tr/official-

statistics.aspx?pageID=1003.

[3] Güçlü, Y. Ş. (2019). Kişi ve Kullanım Bazlı Trafik Sigortası Modelleri ve Türkiye'de Uygulanabilirliği. HAZINE VE MALIYE UZMANLIĞI YETERLIK TEZİ. ANKARA: Yayımlanmamış Uzmanlık Tezi, HAZINE VE MALIYE BAKANLIĞI.

[4] Husnjak, S., Peraković, D., Forenbacher, I., \& Mumdziev, M. (2015). Telematics system in usage based motor insurance. 25th DAAAM International Symposium on Intelligent Manufacturing and Automation, DAAAM (s. 816-825). Vienna: Procedia Engineering.

[5] Toledo, T., Musicant, 0., \& Lotan, T. (2008). Invehicle data recorders for monitoring and feedback on drivers' behavior. Transportation Research Part C: Emerging Technologies. 16(3), 320-331.

[6] Marsh. (2015). Technology in Action - The Road Ahead For the Motor Industry. United Kingdom, https://www.marsh.com/uk/insights/research/te chnology-in-action-the-road-ahead-for-the-motorindustry.html : MARSH \& McLENNAN COMPANIES.

[7] Ayten, B. (2015). Sigorta Dağıtım Süreçlerindeki Yenilikler. Reasürör Dergisi (96), 14-19.

[8] Dharani, S., Isherwood, T., Mattone D. and Moretti, P. (2018). Telematıcs: Polsed For Strong Global Growth. NewYork, USA.: McKinsey\&Company.

[9] Bruneteau, F. (2015). The impact of Telematics on the Motor Insurance Business Model. Munich, Germany.: Scor Global P\&C-Focus.

[10] Julia, D. T. (2017, January 30). The Impact of Telematics on the Motor Insurance Landscape and on. Zurich: Bachelar Thesis, University of Zurich.

[11] Litman, T. (2011). Distance-Based Vehicle Insurance Feasibility, Costs and Benefits . Victoria Transport Policy Institute, 1-10.

[12] Bolderdijk, J. W., Knockaert, J., Steg, E. M., \& Verhoef, E. T. (2011). Effects of Pay-As-You-Drive vehicle insurance on young drivers' speed choice: Results of a Dutch field experiment. ccident Analysis \& Prevention, 43(3), 1181-1186.

[13] LexisNexis. (2014, October). Insurance Telematics: Thinking Outside the Box. White Paper. https://risk.lexisnexis.com/insightsresources/white-paper/insurance-telematicsthinking-outside-the-box.

[14] Weidner, W., Transchel, F. W., \& Weidner, R. (2017). Telematic driving profile classification in car insurance pricing. Annals of Actuarial Science, 11(2), 213-236.

[15] Bian, Y., Yang, C., Zhao, J. L., \& Liang, L. (2018). Good drivers pay less: A study of usage-based vehicle insurance models. Transportation research part A: policy and practice, 107, 20-34.

[16] Dang, J. (2017). The Impact of Telematics on the Motor Insurance Landscape and on Customer Behaviour in the Case of Italy. Zurich, Switzerland: University of Zurich, Department of Business Administration, Bachelor Thesis. 
[17] LexisNexis, R. S. (2020). Moving the Addressable Usage Based Insurance (UBI) Market. Erişim Tarihi: 17.01.2020, https://risk.lexisnexis.co.uk/insightsresources/white-paper/moving-the-addressableusage-based-insurance-ubi-market.

[18] Bordoff, J., \& Noel, P. (2010). Bordoff, J., \& Noel, P. (2010). Pay-as-You-Drive Auto Insurance. E. I. Day içinde, Issues of the Day: 100 Commentaries on Climate, Energy, the Environment, Transportation, and Public Health Policy (s. 150). Washington, DC, USA: Resources For Future.

[19] Goyal, M. (2014). Goyal, M. (2014). Insurance telematics. International Journal of Innovative Research and Development, 3(6), 72-76.

[20] Khazzoom, J. (2000). Khazzoom, J. D. (2000). Pay-atthe-Pump (PATP) Auto Insurance: Criticisms and Proposed Modifications. Resources For Future No. 1318-2016-103400)., 1-34.

[21] Edlin, A. S. (1999). Per-mile premiums for auto insurance. National Bureau of Economic Research. No. w6934, 1-55.

[22] Butler, P., Butler, T., \& Williams, L. L. (1988). SexDivided Mileage, Accident, And Insurance Cost Data Show That Auto Insurers Overcharge Most Women. National Association of Insurance Commissioners, Vol 6, 243-419.

[23] Scor Global P\&C. (2015). Motor Insurance \& Reinsurance Current Issues and Future Events. Paris, France: Focus.

[24] Laurie, A. (2011). Telematics: the new auto insurance. St. Louis, USA: Willis Towers Watson.

[25] Rose, S. (2013). Telematics: How Big Data Is Transforming the Auto Insurance Industry . SAS Institue Inc., 1-9.

[26] Europe Economics. (2009). Retail Insurance Market Study MARKT $/ 2008 / 18 / H$. London, UK: Final Report by Europe Economics .

[27] Desyllas, P., \& Sako, M. (2013). Profiting from business model innovation: Evidence from Pay-AsYou-Drive auto insurance. Research Policy, 42(1), 101-116.

[28] Insurance Information and Monitoring Center. (2019, January 22). https://www.sbm.org.tr/en.

[29] Insurance Law. (2007, June 3). Sigortacılık Mevzuatı. Turkish Insurance Association: Erişim Tarihi:
21.12.2019,

http://www.tsb.org.tr/laws.aspx?pageID=986.

[30] Regulation on Tariff Implementation Principles for Motor Vehicles Compulsory Third Party Liablitiy Insurance. (2018, Aralık 21). Mevzuat. Türkiye Sigorta Birliği: Erișim Tarihi: 23.01.2020, http://www.tsb.org.tr/Default.aspx?pageID=987.

[31] ABI Research (2017), 89 Million Insurance Telematics Subscribers Globally by 2017, https://www.abiresearch.com/press/89-millioninsurance-telematics-subscribers-global/ Erișim Tarihi: 31.08.2020,

[32] IMS. (2019). The Future Trends Uf Usage Based Insurance and Telematics. Erişim Tarihi: 22.01.2020,

https://www.intellimec.com/insights/usagebased-insurance-trends

[33] Gallagher Bassett. (2019, January). Black Boxes \& Telematıcs- Are They The Future Of Car Insurance? Gallagher Bassett: Erişim Tarihi: 22.01.2020, https://www.gallagherbassett.co.nz/black-boxestelematics-are-they-the-future-of-car-insurance/

[34] McKinsey. (2018). Superstars, The Dynamics of Firms, Sectors, And Cities Leading The Global Economy. NewYork: McKinsey \& Company: Discussion Paer.

[35] Fitzpatrick, M. (2019, September 19). Future Outlook of Telematics and the Insurance Industry. The Digital Enterprise: Erişim Tarihi: 22.01.2020, https://www.thedigitalenterprise.com/articles/iot -ar-wearables/future-outlook-of-telematics-andthe-insurance-industry/.

[36] PWC. (2020). Sigorta sektöründe 2020 ve sonrasi: Dönüşüm gereklilikten doğar: Dijitalleșme. Erişim Tarihi:03.01.2020,

https://www.pwc.com.tr/tr/sektorler/sigortacilikbireysel-emeklilik/yayinlar/sigorta-sektorunde2020-ve-sonrasi.html.

[37] Yurdakul, M. \& Dalkılıç, N. (2016). Sigortacılıkta Dijital Çağ. Dumlupınar Ünversitesi Sosyal Bilimler Dergisi, (50), 49-57.

[38] Duffett, R. G. \& Wakeham, M. (2016). Social Media Marketing Communications Effect On Atitudes Among Millennials in South Africa. . The African Journal of Information Systems, 8(3), 20-44. 